\title{
Market Reaction to Bonus Announcement in Post Global Financial Crisis Era: Evidence from India
}

\author{
Mayank Joshipura \\ Mayank Joshipura is Professor (Finance) at School of Business Management \\ NMIMS University, Mumbai, India
}

Nusrathunnisa

School of Business, Alliance University, Bangalore, India

Received: Sep. 26, 2013 Accepted: November 18, 2013 Published: December 1, 2013

doi:10.5296/ajfa.v5i2.4328 URL: http://dx.doi.org/10.5296/ajfa.v5i2.4328

\begin{abstract}
This study examines the stock price reaction contiguous with bonus announcement surrounding its announcement and effective day in post global financial crisis period. Sample of 74 bonus announcements from the constituents of Indian CNX 500 companies that announced bonus have been used for the period between 2008 through 2012. The standard event study methodology has been used. According to semi-strong form of efficient market hypothesis any information content associated with bonus announcement must be reflected in form of abnormal return on announcement day itself. However, several studies, report positive abnormal returns associated with bonus surrounding announcement as well as effective days. This study reports statistically significant positive abnormal return surrounding announcement as well as effective day and it is consistent with earlier studies.
\end{abstract}

Keywords: Bonus Announcement, Market Efficiency, Event Study, Stock Dividend, Market Reaction

JEL Classification: G14 


\section{Introduction}

The relationship between bonus issues and stock prices has been the subject of empirical discussion in finance literature. Under the bonus issue, new shares are issued free of cost to the existing investors by capitalising the reserves, accumulated profits or retained earnings. Bonus issue of 1:1 by a company leads to doubling of number of shares and share capital without changing face value of a share. According to semi-strong form of efficient market hypothesis, if there is any information content associated with bonus announcement it should get reflected on announcement day itself in form of abnormal returns. No abnormal returns should be present on or around ex-date because, the ex-date of bonus issue is known in advance and therefore should not contain any new information. However, several studies, both in developed and developing markets, report significant positive abnormal returns on and surrounding announcement and effective days. There are several hypotheses put forward to explain such effect. However, global financial crisis hit the world economy badly and the entire world is still to find "new normal". In that context is it important to study that whether global financial crisis really altered market reaction to bonus announcement in any manner. The firms announcing stock dividend in tight liquidity markets like the ones seen post global financial crisis may be perceived as looking at growth opportunities for themselves at times where others were struggling to keep their head out of water and finding it hard even to utilize existing capacity. Bonus announcement may well be seen as a signal of the firm's confidence in ability to exploit growth opportunities in difficult times considering the fact that many firms used their reserves to keep paying cash dividends in times when profits were not enough and in many cases were not existent. Announcing stock dividend definitely reduces firm's ability to deep into its reserve to pay cash dividend in difficult times and therefore such announcement in difficult times may certainly speak for itself and firm's confidence about its future. However, it may turn out to be a double edged sword if things don't go as per plan. The current study examines the stock price reaction contiguous with bonus announcement surrounding its announcement and effective day in post global financial crisis period to see how market looks at such action by a firm and adds new findings to the existing literature by examining whether Indian stock market is semi- strong efficient or not. The study attempts to answer this empirical question of informational content of stock dividend announcements using standard event analysis methodology.

The paper from hereon is divided into following sections. Section II discusses review of literature, section III elaborates on methodology, section IV focuses and discussion of results and section $\mathrm{V}$ is conclusion.

\section{Review of Literature}

Numerous empirical studies have found that announcement of bonus issues / stock splits are associated with significant stock price reactions upon announcement. Many exigent hypotheses have been proposed in the literature to explain this market behaviour. Signaling hypothesis and liquidity hypothesis have emerged as the two leading explanations for this market behaviour.

Ball, Brown and Finn (1977) investigated stock price reaction around the announcement of 
'stock capitalisation changes' (bonus stock issues, stock splits and rights issues) in Australia for the period between 1960 and 1969 inclusive using monthly data and found 20.2\% abnormal return for 13 months up to including the month of bonus issue announcements. Foster and Vickrey (1978) examined daily returns around announcement and determined whether stock dividend announcements cause investors to change their expectations concerning future firm prospects. In their examination of the information content for 82 stock dividend announcements, they found significant positive abnormal returns around announcement dates. Woolridge (1983) examines the daily returns around 317 stock dividend announcements controlled for earnings announcements and cash dividend payments and found that stock dividend announcements are interpreted by investors as positive signals from managers about the future business operations. Grinblatt, Masulis and Titman (1984) examined stock splits and stock dividends under the traditional signaling model and suggested that it can be considered as a costly signal. In case of stock dividends, the reduction in retained earnings will restrict the firm's stability to pay cash dividends if the firm does not anticipate increased earnings. Doran and Nachtmann (1988) using a sample of 879 firms which issued stock dividends between 1971 and 1982 reports that bonus announcements led to upward revision of earnings expectations that is similar to attention getting hypothesis. Ghosh and Woolridge (1988); Banker, Das, and Datar (1993) investigate the cash substitution hypothesis and find negative stock price reaction to dividends cuts and omissions could be offset by an announcement of stock dividend as a substitute. Lijleblom (1989) examines the signaling hypothesis of stock dividend and stock splits for stocks listed on the Stockholm Stock Exchange (SSE). The problem of simultaneous announcements of other information is present in $90 \%$ of the cases at (SSE). The contaminating effects of earnings and dividend announcements are controlled by using a control group of otherwise similar stocks but which do not split or distribute a stock dividend. They find significantly high price reactions for the stock dividend/split group than the control group which is interpreted as support for the signaling hypothesis in the presence of contaminating announcements. McNichols and Dravid (1990) provide further evidence to support the signaling hypothesis and reported positively significant abnormal returns on the day of stock dividend announcement. Further they find that both small stock dividend factor sample (less than 10\%) and large stock dividend factor sample show statistically significant abnormal returns on the announcement day. Masse et al. (1997) examined the announcement day impact of stock splits, reverse splits and stock dividends of Toronto Stock Exchange from 1975-94. Abnormal returns are derived using the mean adjusted returns model, the market adjusted returns model and the simple ordinary least square market model. For the stock dividends, abnormal returns are positive from day 0 to day 2 and on day 0 and day 1 average abnormal return are statistically significant at $1 \%$ level. In a nutshell, there are several hypotheses put forward to explain the positive abnormal returns associated with bonus announcements. Mohanty (1999) found that firms which issued bonus shares, have either maintained the payout at the pre-bonus level or only decreased it marginally thereby increasing the payout to shareholders. Papaioannou et al. (2000) found no significant abnormal returns on and around announcement period as in Greece it is compulsory requirements imposed upon firms to satisfy the legal requirements a However their research environment is quite different from other markets, stock dividends in Greece are not initiated by firms but they are compulsory requirements imposed upon firms to satisfy legal requirements and any stock dividend announcement should get the approval 
from the shareholders along with the terms of the distribution. Balachandran et al. (2004) observed positive and statistically significant abnormal returns for the announcement day to the following day and found that abnormal returns or contaminated events outperform the uncontaminated events on day 0 . However difference of abnormal returns is not statistically significant.

Given below is a summary of main hypothesis floated around to explain market reaction to bonus announcement.

Signaling hypothesis (Grinblatt et al. (1984); McNichols \& Dravid (1990); Masse et al. (1997)) that suggests that 'the bonus announcement conveys new information to the market in instances where managers have asymmetric information'.

Cash substitution hypothesis: While signaling hypothesis received massive support, (Ghosh \& Woolridge (1988); Banker, Das, and Datar (1993) float cash substitution hypothesis which suggests that the firm can conserve cash by issuing bonus as a substitute of cash dividend without facing adverse reaction from market due to lowering or omitting cash dividend.

Attention getting hypothesis: Grinblatt et al. (1984); Doran and Nachtmann (1988) attribute positive abnormal returns associated with announcement of bonus to attention getting hypothesis suggesting that bonus announcement draws market attention and further leads to demand for the stock of the firm announcing stock dividend.

Liquidity hypothesis: Lakonishok and Lev (1987) investigate that stock dividend announcements intends to improve liquidity by creating additional stocks and that should lead to more trading and greater ownership dispersion in a firm.

Studies on bonus announcements in Indian markets offer interesting findings. Obaidullah (1992) reports positive wealth effect associated with bonus issue. He also finds evidence for semi-strong form of EMH for Indian markets. Rao (1994) reports significant positive price effect just after announcement and finds evidence of semi strong form of market efficiency in Indian markets. Mishra (2005) reports positive abnormal return on and around announcement day associated with bonus announcement but does not find any significant abnormal return on effective day. He reports $-0.10 \%$ return on effective day which also provides significant support to singling hypothesis and evidence of semi strong form of market efficiency from Indian markets. Joshipura (2009) also reports positive abnormal returns on and around announcement of bonus and nothing around ex-date. He further reports negative abnormal returns in relatively longer post effective day window. Ray (2011) reports no price effect associated with bonus announcements on or around announcement or ex-date.

\section{Methodology}

\section{A. Sample \& Data source}

The study constituted 74 bonus issues by constituent companies listed on CNX Nifty 500 from the period 2008 to 2012. Bonus announcement information is collected from the Capitaline database. Adjusted daily closing price data for each company over the period of 
130 trading days before to and 10 trading days after the ex-date are used for the study.

\section{B. Measuring price effect}

The approach used to achieve above-mentioned objective is known as "event study" which is a standard approach in the area of financial economics ever since it has been published by Fama et al (1969). An event study is designed to examine market reaction of any event under observation using abnormal return criteria.

For this study, we have divided data into various windows.

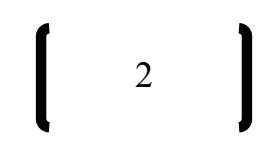

Choice of length for event and estimation windows has remained as contentious issue among scholars over the years. Windows for the present study are defined as given below.

Event windows: AD-10 to AD+10 and ED-10 to ED+10: Event window AD-10 to AD+10 is used to check any leakage prior to formal announcement of index changes. Absence of abnormal return on the announcement and not before or after that can be interpreted as evidence for semi-strong form of EMH if there is any information content associated with such announcement. ED-10 to ED+10 days is used as effective window. Ideally, no abnormal return should be present on or around ex-date but presence of any such return may be evidence against semi-strong form of EMH or requires logical explanation it is not the case.

The first step in this process of determining price or wealth effect is to calculate abnormal return.

To perform the analysis, first the equilibrium model for the normal stock return, that is the expected return if the event did not happen, must be specified. Second, we need to identify the event date and the event window that is the period over which the security returns will be examined. The model is estimated outside this window, by choosing period of AD-30 to AD-130 days which is the standard practice in most such studies. The forecast errors over the event window measure the abnormal performance of returns associated with the event. The normal model most widely used in the event-studies is the market model which can be expressed as

$$
R_{i, t}=\alpha_{i}+\beta_{i} R_{m, t}+\xi_{i, t}
$$

Where,

$\mathrm{R}_{\mathrm{i}, \mathrm{t}}$ is the return on security $\mathrm{i}$ on day $\mathrm{t}$

$\mathrm{R}_{\mathrm{m}, \mathrm{t}}$ is the return on a market index on day $\mathrm{t}$

$\alpha i$ is market model constant

$\beta \mathrm{i}$ is a parameter that measures the sensitivity of $\mathrm{Ri}$ to the benchmark market index

$\xi \mathrm{i}, \mathrm{t}$ is a random error term of market model OLS regression with expected value of zero.

The event dates are the announcement date (AD), the day when bonus is announced and effective day (ED), the day on which stock goes ex-bonus. Market model is estimated using 


\section{Macrothink

estimation window and abnormal returns for every day during event windows are calculated as below.

$$
A R_{i, t}=R_{i, t}-\alpha_{i}-\beta_{i} R_{m, t}
$$

In order to draw overall inferences for the event of interest, the abnormal return observations measured across securities. The following measures of abnormal performance are used:

- Cumulative Abnormal Return (CAR): cumulative sum of stock it's prediction error (abnormal returns) over the window $\left(\mathrm{t}_{1}, \mathrm{t}_{2}\right)$

$$
C A R_{i, t}=\sum_{t 1}^{t 2} A R_{i, t}
$$

- Mean Abnormal Return (MAR): An average of abnormal returns across the $\mathrm{N}$ firms on a day $t$.

$$
M A R_{t}=\frac{1}{N} \sum_{i=1}^{N} A R_{i, t}
$$

- Mean Cumulative Abnormal Return (MCAR): average of the cumulative abnormal returns across observations (firms); it is a measure of the abnormal performance over the event period,

$$
\operatorname{MCAR}_{t}=\frac{1}{N} \sum_{i=1}^{N} C A R_{i, t}
$$

\section{Testing for statistical significance}

The cross-sectional t-test using cross-sectional variance is performed for both MAR and CAR. The sample equation for calculation of cross sectional variance for MAR is given below.

$$
S^{2}=\frac{1}{N} \sum_{i=1}^{N} \frac{\left(A R_{i t}-M A R_{t}\right)^{2}}{N-1}
$$

A nonparametric generalized sign test based on sign of abnormal return is also employed. The hypothesis is abnormal returns are independent across securities and that the expected proportion of positive abnormal returns under the null hypothesis is 0.5 . The test statistic is computed as $\theta=\left[\frac{N^{+}}{N}-0.5\right] \frac{\sqrt{N}}{0.5} \sim N(0,1)$ where $\mathrm{N}$ is the sample size and $\mathrm{N}^{+}$is the number of cases where the abnormal return is positive. This test is conducted to add robustness of the study. 


\section{Results and Discussion}

Table 1. Mean Abnormal Returns within Announcement Window

\begin{tabular}{|c|c|c|c|c|}
\hline Days & t-stat & MAR & positive (out of 74) & z-score \\
\hline $\mathrm{AD}-10$ & 0.31 & $0.04 \%$ & 35 & -0.46 \\
\hline $\mathrm{AD}-9$ & 2.73 & $0.32 \%$ & 39 & 0.46 \\
\hline $\mathrm{AD}-8$ & 1.67 & $0.19 \%$ & 40 & 0.7 \\
\hline $\mathrm{AD}-7$ & 0.76 & $0.09 \%$ & 33 & -0.93 \\
\hline $\mathrm{AD}-6$ & 1 & $0.12 \%$ & 37 & 0 \\
\hline $\mathrm{AD}-5$ & -0.36 & $-0.04 \%$ & 34 & -0.7 \\
\hline $\mathrm{AD}-4$ & 0.43 & $0.05 \%$ & 42 & 1.16 \\
\hline $\mathrm{AD}-3$ & 2.77 & $0.32 \%$ & 41 & 0.93 \\
\hline $\mathrm{AD}-2$ & 2.12 & $0.25 \%$ & 44 & 1.63 \\
\hline $\mathrm{AD}-1$ & 2.16 & $0.25 \%$ & 46 & 2.09 \\
\hline $\mathrm{AD}$ & 4.34 & $0.50 \%$ & 50 & 3.02 \\
\hline $\mathrm{AD}+1$ & 0.81 & $0.09 \%$ & 35 & -0.46 \\
\hline $\mathrm{AD}+2$ & -2.98 & $-0.35 \%$ & 27 & -2.32 \\
\hline $\mathrm{AD}+3$ & 0.53 & $0.06 \%$ & 36 & -0.23 \\
\hline $\mathrm{AD}+4$ & -0.26 & $-0.03 \%$ & 35 & -0.46 \\
\hline $\mathrm{AD}+5$ & -0.96 & $-0.11 \%$ & 28 & -2.09 \\
\hline $\mathrm{AD}+6$ & -0.07 & $-0.01 \%$ & 39 & 0.46 \\
\hline $\mathrm{AD}+7$ & -1.57 & $-0.18 \%$ & 33 & -0.93 \\
\hline $\mathrm{AD}+8$ & -0.6 & $-0.07 \%$ & 37 & 0 \\
\hline $\mathrm{AD}+9$ & -0.62 & $-0.07 \%$ & 35 & -0.46 \\
\hline $\mathrm{AD}+10$ & -0.11 & $-0.01 \%$ & 35 & -0.46 \\
\hline
\end{tabular}

Table 1 reports the Mean Abnormal returns (MAR) during the announcement window. It is interesting to notice that the MAR is positive and statistically significant with value of $0.32 \%$ on AD-3. However, only 41 out of 71 firms have positive abnormal returns for AD-3 and it is not significant on non-parametric sign test. . AD-2 is the day when market gets the sniff of bonus announcements and statistically significant positive abnormal return of $0.25 \%$ with. Positive abnormal returns for 44 out of 74 firms that is statistically significant on sign test as well. abnormal returns becoming more and more significant with higher values and more number of firms are observed with positive abnormal returns. $0.25 \%$ of MAR is observed on AD-1 with 46 out of 74 firms with positive abnormal returns. Presence of positive abnormal returns just prior to announcement day is probably indicating some leakage of information or some early signals for market participants on potential bonus announcement. However, the largest MAR of $0.5 \%$ is observed on the announcement day with 50 out of 74 firms having positive abnormal return and that is highly significant $t$ and $z$ value However, significant positive MAR is not seen anywhere in the remaining length of announcement window $(A D+1$ to $\mathrm{AD}+10$ ). In fact, statically significant negative MAR of $0.35 \%$ is observed and that is significant with 47 out of 74 firms with negative abnormal returns. 
Table 2. Mean Cumulative Abnormal Returns within announcement Window

\begin{tabular}{|c|c|c|c|c|}
\hline Days & t-stat & MCAR & positive (out of 74) & z-score \\
\hline $\mathrm{AD}-10$ & 0.38 & $0.04 \%$ & 35 & -0.46 \\
\hline AD -9 & 2.05 & $0.35 \%$ & 40 & 0.7 \\
\hline $\mathrm{AD}-8$ & 2.39 & $0.55 \%$ & 41 & 0.93 \\
\hline $\mathrm{AD}-7$ & 2.41 & $0.64 \%$ & 41 & 0.93 \\
\hline $\mathrm{AD}-6$ & 2.65 & $0.75 \%$ & 42 & 1.16 \\
\hline $\mathrm{AD}-5$ & 2.42 & $0.71 \%$ & 37 & 0 \\
\hline $\mathrm{AD}-4$ & 2.44 & $0.76 \%$ & 39 & 0.46 \\
\hline $\mathrm{AD}-3$ & 3.02 & $1.08 \%$ & 45 & 1.86 \\
\hline $\mathrm{AD}-2$ & 3.5 & $1.33 \%$ & 47 & 2.32 \\
\hline $\mathrm{AD}-1$ & 4.03 & $1.58 \%$ & 50 & 3.02 \\
\hline $\mathrm{AD}$ & 5.08 & $2.08 \%$ & 54 & 3.95 \\
\hline $\mathrm{AD}+1$ & 4.79 & $2.18 \%$ & 55 & 4.18 \\
\hline $\mathrm{AD}+2$ & 3.87 & $1.83 \%$ & 50 & 3.02 \\
\hline $\mathrm{AD}+3$ & 4.06 & $1.89 \%$ & 47 & 2.32 \\
\hline $\mathrm{AD}+4$ & 3.82 & $1.86 \%$ & 46 & 2.09 \\
\hline $\mathrm{AD}+5$ & 3.65 & $1.75 \%$ & 46 & 2.09 \\
\hline $\mathrm{AD}+6$ & 3.65 & $1.74 \%$ & 48 & 2.56 \\
\hline $\mathrm{AD}+7$ & 3.29 & $1.56 \%$ & 48 & 2.56 \\
\hline $\mathrm{AD}+8$ & 3.13 & $1.49 \%$ & 46 & 2.09 \\
\hline $\mathrm{AD}+9$ & 2.98 & $1.42 \%$ & 46 & 2.09 \\
\hline $\mathrm{AD}+10$ & 2.99 & $1.41 \%$ & 44 & 1.63 \\
\hline
\end{tabular}

Table 2 reports Mean Cumulative Abnormal return (MCAR) within the announcement window. MCAR also shows similar trend to MAR values and is significant both with $\mathrm{t}$ and $\mathrm{z}$ statistics from AD-2 and reaches its pick on AD+1 with MCAR of $2.18 \%$ with 55 out of 74 firms reporting positive MCAR and that is highly significant both using parametric t-test and non-parametric sign test. While MCAR remains statistically significant for the remaining length of announcement window post announcement day (AD+1 to $A D+10)$, it fizzles out at a steady pace with MCAR of $1.41 \%$ on $\mathrm{AD}+10$ and only 44 out of 74 firms with positive MCAR value compared to $2.18 \%$ MCAR with 55 firms with positive MCAR value on AD+1. This indicates that bonus announcement shows positive market reaction in anticipation of such announcement before one or two days of such announcement with significant positive response on the bonus announcement day itself-the way it should be if markets are efficient in its semi strong form and bonus announcement is perceived as a positive information about the stock. 
Table 3. Mean Abnormal Returns within Effective Window

\begin{tabular}{|c|c|c|c|c|}
\hline Days & t-stat & MAR & positive (out of 74) & z-score \\
\hline ED -10 & -0.68 & $-0.08 \%$ & 34 & -0.59 \\
\hline ED -9 & -1.92 & $-0.22 \%$ & 27 & -2.22 \\
\hline ED -8 & 1.59 & $0.19 \%$ & 40 & 0.82 \\
\hline $\mathrm{ED}-7$ & 0.99 & $0.12 \%$ & 39 & 0.59 \\
\hline ED -6 & 2.74 & $0.32 \%$ & 45 & 1.99 \\
\hline ED -5 & 2.54 & $0.30 \%$ & 46 & 2.22 \\
\hline ED -4 & 2.01 & $0.24 \%$ & 43 & 1.52 \\
\hline ED -3 & 0.59 & $0.07 \%$ & 41 & 1.05 \\
\hline ED -2 & -0.22 & $-0.03 \%$ & 35 & -0.35 \\
\hline ED -1 & 0.35 & $0.04 \%$ & 34 & -0.59 \\
\hline ED & 4.95 & $0.58 \%$ & 46 & 2.22 \\
\hline $\mathrm{ED}+1$ & 0.1 & $0.01 \%$ & 30 & -1.52 \\
\hline $\mathrm{ED}+2$ & -2.79 & $-0.33 \%$ & 22 & -3.39 \\
\hline $\mathrm{ED}+3$ & -1.29 & $-0.15 \%$ & 27 & -2.22 \\
\hline $\mathrm{ED}+4$ & -1.89 & $-0.22 \%$ & 24 & -2.93 \\
\hline $\mathrm{ED}+5$ & -0.14 & $-0.02 \%$ & 31 & -1.29 \\
\hline $\mathrm{ED}+6$ & -3.74 & $-0.44 \%$ & 24 & -2.93 \\
\hline $\mathrm{ED}+7$ & -1.95 & $-0.23 \%$ & 29 & -1.76 \\
\hline $\mathrm{ED}+8$ & -2.95 & $-0.35 \%$ & 23 & -3.16 \\
\hline $\mathrm{ED}+9$ & -3.5 & $-0.41 \%$ & 22 & -3.39 \\
\hline $\mathrm{ED}+10$ & -1.67 & $-0.20 \%$ & 32 & -1.05 \\
\hline
\end{tabular}

Table 3 reports Mean Abnormal Returns (MAR) surrounding ex-bonus date. While there is no significant positive abnormal return observed within effective window prior to ex-bonus date, highly significant positive abnormal return of with MAR of $0.58 \%$ is observed in 46 out of 74 firms and that can be attributed to the split like effect where investors may perceive that stock as more affordable and cheap and that might have created some demand. It is more evident due to the fact that between ED +1 to ED+10 there are several days on which significant MAR is seen and that means the positive market reaction seen on the ex-day was just temporary and reversed in a very short period of time. If such positive reaction is due to improvement in liquidity or more permanent positive shift in demand such positive abnormal returns would have sustained. 
Table 4. Mean Cumulative Abnormal Returns within Effective Window

\begin{tabular}{|c|c|c|c|c|}
\hline Days & t-stat & MCAR & positive (out of 74) & z-score \\
\hline ED-10 & -0.72 & $-0.08 \%$ & 34 & -0.59 \\
\hline ED -9 & -1.97 & $-0.30 \%$ & 31 & -1.29 \\
\hline ED -8 & -0.65 & $-0.12 \%$ & 35 & -0.35 \\
\hline ED -7 & -0.01 & $0.00 \%$ & 35 & -0.35 \\
\hline ED -6 & 1.21 & $0.32 \%$ & 43 & 1.52 \\
\hline ED -5 & 2.11 & $0.62 \%$ & 49 & 2.93 \\
\hline ED -4 & 2.77 & $0.85 \%$ & 51 & 3.39 \\
\hline ED -3 & 2.76 & $0.92 \%$ & 48 & 2.69 \\
\hline ED -2 & 2.13 & $0.89 \%$ & 48 & 2.69 \\
\hline ED -1 & 2.23 & $0.93 \%$ & 46 & 2.22 \\
\hline ED & 3.77 & $1.51 \%$ & 50 & 3.16 \\
\hline $\mathrm{ED}+1$ & 3.73 & $1.53 \%$ & 48 & 2.69 \\
\hline $\mathrm{ED}+2$ & 2.76 & $1.20 \%$ & 41 & 1.05 \\
\hline $\mathrm{ED}+3$ & 2.32 & $1.05 \%$ & 40 & 0.82 \\
\hline $\mathrm{ED}+4$ & 1.92 & $0.83 \%$ & 41 & 1.05 \\
\hline $\mathrm{ED}+5$ & 1.75 & $0.81 \%$ & 38 & 0.35 \\
\hline $\mathrm{ED}+6$ & 0.87 & $0.37 \%$ & 36 & -0.12 \\
\hline $\mathrm{ED}+7$ & 0.33 & $0.15 \%$ & 35 & -0.35 \\
\hline $\mathrm{ED}+8$ & -0.44 & $-0.20 \%$ & 32 & -1.05 \\
\hline $\mathrm{ED}+9$ & -1.31 & $-0.61 \%$ & 29 & -1.76 \\
\hline $\mathrm{ED}+10$ & -1.65 & $-0.81 \%$ & 27 & -2.22 \\
\hline
\end{tabular}

Table 4 reports Mean Cumulative Abnormal Returns surrounding ex-bonus date. MCAR turns significant positive from ED-5 and remains till ED +5 with $\mathrm{ED}+1$ report highest MCAR of $1.53 \%$. MCAR remains statically significant and positive till ED+5 but it declines continuously from $\mathrm{ED}+1$ high levels. MCAR is $0.81 \%$ on $\mathrm{ED}+5$ that is statistically significant but at a level that is much below $1.53 \%$ observed on ED+1. MCAR keeps on declining from thereon and finally ends with negative $0.81 \%$ MCAR on last day of effective window that is $\mathrm{ED}+10$, a complete reversal of trend.

\section{Conclusion}

In this paper, we analyse market reaction surrounding announcement and ex-bonus days in post global financial crisis era in Indian markets. Our results show that bonus announcement leads to some buzz in the market and it reacts positively to such announcements. If, market is efficient in its semi-strong form, such positive reaction associated with bonus announcement should be restricted on announcement day only, however, we can see that market gets some hint of such potential announcement at least two days before but the biggest positive market reaction is observed on announcement day itself and not on any of the following day in the 
announcement window. That indicates that bonus announcement do carry positive information content and that is getting reflected just before and immediately on its announcement and that provides support for information content and some evidence of Indian stock market is efficient in its semi-strong form. While, bonus announcement does not change anything substantially, capitalization of reserve is probably considered as a positive sign by the market as that indicates that the firm announcing bonus is confident of serving higher capital base for distributing future dividends and also the fact that it may not need reserves to deep into for distributing cash dividends especially in bad times. Positive market reaction is observed on the ex-bonus date but fizzles out immediately after that and results in reversals by the end of effective window that indicates that such reaction is only on account of some overreaction on the ex-day and that reverses itself soon after. Overall, our study concludes that bonus announcement does carry positive information content and that leads to positive market reaction on its announcement and such reaction is not following through beyond announcement day and that endorse that Indian stock market is efficient in its semi-strong form. Besides, positive market reaction on ex-bonus day is just overreaction by market participants and it reverses itself immediately thereafter.

The results are consistent with other studies in Indian markets by Mishra (2005) and Joshipura (2009), where they reported significant positive price effect on announcement day itself. However, the results of this study are different from those studies on ex-day returns-those studies did not report any positive price effect on ex-day, in fact Mishra (2005) reports negative return on ex-day whereas, present study reports positive return on the ex-bonus day. However, such positive returns reverse immediately and hence not significant by any means. Results of present study are not consistent with Ray (2011) as he reports no price reaction surrounding announcement as well as effective date.

To summarize, results of the present study support signaling hypothesis and provides evidence that Indian markets are efficient its semi strong form with small leakage of information pertaining to the bonus announcement just prior to formal announcement.

\section{References}

Balachandran.B, F. a. (2004). Further Evidence on the Announcement Effect of Bonus Shares in an Imputation Tax Setting. Golbal Fiancial Journal, 15(2), 147-170, http://dx.doi.org/10.1016/j.gfj.2004.02.001.

Ball, Ray; Brown, Philip; Finn, Frank J. (1977, October). Share Capitalization Changes, Information and the Australian Equity Market. Australian Journal of Management, 2(2), 105-126, http://dx.doi.org/10.1177/031289627700200202.

Banker. R., S. Das, and S. Datar. (1993). Complementarity of Prior Accounting Information: The Case of Stock Dividend Announcements. Accounting Review, 68(1), 28-47.

Doran, D.T. and Nachtmann R. (1988). The Association of Stock Distribution Announcements and Earnings Performance. Journal of Accounting, Auditing and Finance, 3(2), 113-132. 
Foster III, T. W., and Vikery, D. (1978). The information Content of Stock Dividend Announcements. Accounting Review, 53(2), 360-370.

Ghosh, C., and Wollridge, J. (1988). An Analysis of Shareholder reaction to Dividend Cuts and Ommisions. Journal of Financial Research, 11(4), 281-294.

Grinblatt, M. S., Masulis, R. W., and Titman, S. (1984). The Valuation Effects of Stock Splits and Stock Dividends. Journal of Financial Research, 13(4), 461-490.

Joshipura M. (2009). Price and Liquidity Effects of Bonus Announcements: Empirical Evidence from Indian Stock Market. IUP Journal of Applied Finance, 15(11), 5-23.

Lakonishok, J., and Lev, B. (1987). Stock Splits and Stock Dividends: Why, Who and When. Journal of Finance, 42(4), 913-932, http://dx.doi.org/10.1111/j.1540-6261.1987.tb03939.x.

Lijleblom, E. (1989). The Informational Impact of Announcements of Stock Dividends and Stock Splits. Journal of Business Finance and Accounting, 16(5), 681-698, http:/dx.doi.org/10.1111/j.1468-5957.1989.tb00047.x.

Masse, I., Hanrahan,J.R. and Kushner, J. (1997). The Effect of Canadian Stock Splits, Stock Dividends and Reverse Splits on the Value of the Firm. Quarterly Journal of Business and Economics, 36(4), 51-62.

Mcnichols, M. and Dravid, A. (1990). Stock Dividends, Stock Splits, and Signaling. Journal of Finance, 45(3), 857-879, http://dx.doi.org/10.1111/j.1540-6261.1990.tb05109.x.

Mishra, A. (2005). An Empirican Analysis of Market Reaction Around the Bonus Issue in India. Working Paper(2005-10).

Mohanty, P. (1999). Dividend and Bonus Policies of Indian Companies: An Analysis. Vilalpa: The Journal of Decision Makers, 24(4), 35-42.

Obaidullah, M. (1992). How Do Stock Prices React to Bonus Issues? Vikalpa: The Journal of Decision Makers, 17(1), 17-22.

Papaioannou, G. J., Travlos, N. G. and Tsanarakis, N. V. (2000). Valuation Effects of Greek Stock Dividend Distributions. European Financial Management, 6(4), 515-531, http://dx.doi.org/10.1111/1468-036X.00137.

Rao, S. N. (1994). The Adjustment of Stock Prices to Corporate Financial Policy Announcements. Finance India, 8(4), 941-953.

Ray, Koustubh Kanti. (2011). Market Reaction to Bonus Issues and Stock Splits in India: An Empirical Study. IUP Journal of Applied Finance, 17(1), 54-69.

Woolridge, R. (1983). Stock Dividends as Signals. Journal of Financial Research, 6(1), 1-12. 